\title{
第39回総会 一般演説記事
}

\section{第 2 日 昭和 52 年 10 月 22 日}

\section{B 会場 午前の部}

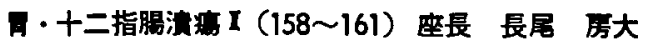

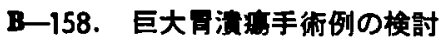 武蔵野赤十字病院外科 \\ 江崎 昌俊，浅野 元和, 德永 剛 㚼尾 正彦，高橋 腾三}

過去11年間の胃漬晹手術192例中，新鮮切除標本にて 最大经 $3.0 \mathrm{~cm}$ 以上かつ最小径 $1.5 \mathrm{~cm}$ 以上の巨大胃潰演 につき症例の分析を行ない，その臨床的特徽と外科治療 上の留意点を検討した。

<巨大胃潰堭の特改〉

(1) 巨大胃潰湯は30歳以降既に分布するが，巨大化寸 るにつれて平均年跲が上昇し，最大径 $5 \mathrm{~cm}$ 以上では 60

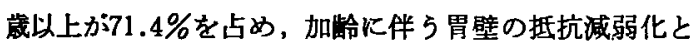
修覆能低下が巨大化に導くと考光られる，精神的ストレ

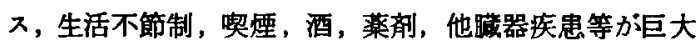
化因子として作用することす確認した．(2) 病恫期間中 疼痛㕵度は漬湯の大きさと相関しない. (3) 出血は79\% であるが，遊離穿孔は $6 \%$ と少ない，演瘍が巨大化す れば出血の頻度は增大するが，穿孔の頻度は影響され ず，発生部位が問題である。 (4) 発生部位は胃体上部の 小弯，次後壁に多い。(5) 深達度はUl IVが80\%を 占める。 (6) 他䐵器穿通は75.7\%に達し, 腆が最も多 い.

\section{<外科治療上の留意点＞}

(1) 早期手術の必要性：（1）加龄に伴万胃壁の退行 性变性に上る防蘩因子の低下並びに修覆能低下か下地に あり，結局，難治性となり易い（2）他䁍器穿通障害，

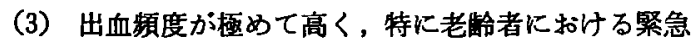
手衡の危険珄，（4）癌潜在の可能性. 以上の如き問題 を含んで打り，その手術適応に関しては早目に手術時期 を决定すべきで，いたずらに保存的療法に頼るべきでな W.

(2) 手術について：手術は上記留意点を考慮すると潰 第を含む胃切除を施行すべきである，広範胃切，分節胃 切，噴切等を潰癔発生部位に応して選択する。悪性との
鑑別上，術中胃切開，迅速病理診断を適宣行なら．以上 の方針で我々は满足なる成績を得たので報告した。

\section{B-159. 高位暴演の特徽之治康対策} 慈恵医科大第 2 外科

中村 紀夫, 桜井 健彦、長洲 堯雄

田口 義文, 坂口友次朗, 岩崎 晃

小山厚, 田村 茂樹, 青木 照明

長尾 房大

通常の胃蛽湯には，左胃動脈最終前枝と左胃大網動脈 最終前枝とを結.゙線を胃切除線として幽門側部分切除術 を行なっているが，溃愓がの切除線よりさらに高位口 側にある場合は「高位演瘍」として胃互全摘ならびに噴 門側切除術を施行している. 今回, 高位潰場の治療対策 のうえから，これら切除胃に組織形態学的な検討を加 之，その特徵を明らかにし得たので報告する．梌査材料 は亜全摘胃24例，噴切胃19例，計43例である．胃粘膜構 浩から演晹の発生部位をみると，明らかに胃底腺領域内 にあるるの ( I 型) 28 例 $(65 \%$ )，胃粘膜変化が强く腺 境界が不明で潰愓の存在する腺領域を決定し兄ないもの （II 型）12例 (28\%)，幽門腺領域内にあるるの（II 型） 3 例 ( $7 \%$ ) となり，胃底腺領域の溃場がもっとも多か った．このらち亜全摘胃で I 型を示す16例について，粘 膜境界部およひ漬瘍の位置を計測してみると，幽門輪か ら潰瘍までは， $12.1 \pm 2.2 \mathrm{~cm}$ となり，境界部までは， 小弯で, $7.9 \pm 1.6 \mathrm{~cm}$, 大弯で $5.7 \pm 1.3 \mathrm{~cm}$ となり, 胃底 腺領域はかなり広いといえる。

「高位演瑒胃」K拈ける粘膜变化は，腸上皮化生と土 ロシオンであるが，腸上皮化生は，II 型，吕型に高頻度 でみられ，その程度も高度のむのが多い。エロジオン は，胃体部から胃底部へかけて前後暨にみとめられ小弯 や幽門部には少い，I型に多く，II 型，II 型では少いと いら傾向を示している。

以上，「高位溃湯胃」の形態学的な特徽から治療上の 問題点をあげると，「(1) 胃底腺領域内の演瘍が多いこ と. (2) 胃体部から胃底部にかけての胃底腺領域にエロ 
シオンが多発していること。(3) 亚全摘胃のI 型にかぎ ってい妄ば，胃底腺領域か広く，小弯で幽門輪から7.9 $\mathrm{cm}$ ，大弯で $5.7 \mathrm{~cm}$ であること.」となろら．これらの点 をらまえた胃切除範囲の決定，手術々式の選択が必要な ことと考える。

\section{B-160. 高位胃暴满に対する迷切合并術式の模討} 徳島大学第 1 外科

森下 和哉, 渡辺 英生, 櫛田 俊明 江口隆夫，喜多 孝志，田村 利和 堤 健, 中田 昭愷, 桑島 輝夫 古味 信意

高位胃溃婸に対して最近，幽門形成術を追加しない迷 切合併術式を行なっている．今回は噴門側切除例を除く SPV 症例22例について検討を加光た。内訳は Punch out 5 例（1 例は幽門形成術），分節胃切除術17例（12例は 門形成術）である。また SPV十分節胃切除を行なっ た大胃筋電図についても報告する，衍前の主訴としては 吐血，下血が11例と多く，ダンピング症候群化よる再手 術 1 例である.テトラガストリンKよる徒後の隇酸率は 83\%であり，各術式間仁差はみられない，インシュリン テストでは1例が late positiveであり，他は negative であった，血清ガストリン值は空腹時，肉汁刺激、イン

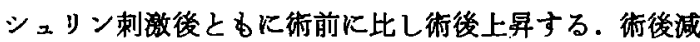
酸効果と相まって幽門洞が温存されているためである 5.術後 1 カ月目の胃排泄時間を此較すると，各術式間 で著しい差はないが，SPV+分節胃切除術後にやゃ胃排 出時間の遅延寸る傾向がみられた．SPV+分節胃切除術 症例の衍後胃運動をレ線映画で観察すると，1 カ月目て

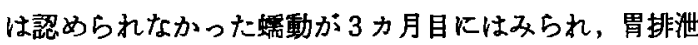
時間も軽度延長している症例がみられるのみであった。 イヌに打いて，SPV十分節胃切除海門形成術を施行し ない例に括ける BER の変動は，約 3 週以啳に術前の状 態に回復した。伝播速度は 4 週以後に回復したが，分節 下部では術前に比し約30\%の減少をみた．SPV+分節胃 切除に幽門形成衍を行なかなかった症例において，術後 胃運動がられたのは 1 力月以降であり，又，動物実験 に打いてす同様でありここの術式を行なった場合には術 後 1 カ月余にわたり十分な観察か必要である.以上より 幽門形成術は必ずしる必要と思わないが，今後症例を重 ねて検討したい。

\section{B-161．高位胃港演に対する術式の模討} 爱嫒県立中央病院外科

棔原 幸雄, 江里口健次郎, 田中富雄
重松授，小笠原悦男, 川本浩一郎 木村 誉司，佐々木文生，坂田 正毅 高位胃海瘍に対する手術術式としては，Madlener 手 術を始めとして，広範用の噴門側または分節胃体部切除 街など各種の方式が行なわれてきた。

われわれる噴門側または分節胃体部切除術に迷走神経 切断術（迷切）を組み合せることにより胃切除範用を小 範围にとどめつつ，術後胃機能の温存をはかる術式を試 みてきた。

取り扱った症例は25例であり，術式の内訳は次のよう である。

I . 迷切併用噴門側胃切除術一 3 例

1) $\mathrm{SV}+$ Prox $+\mathrm{PP} \quad 1$ 例

2) $\mathrm{SPV}+\mathrm{Prox}+\mathrm{PP} \quad 1$ 例

3) SPV+Prox (without PP) 1 例

II . 迷切剙用分節胃体部切除術一22例

1) $\mathrm{SV}+\mathrm{Seg}+\mathrm{PP} \quad 2$ 例

2) $\mathrm{SPV}+\mathrm{Seg}+\mathrm{PP}$ 13例

（十二指腸潰湯共存 5 例を含む）

3) $\mathrm{SPV}+\mathrm{Seg}$ (without PP) 7 例

すなわち，高位胃謴湯に対しては食道噴門部切除を避 けるため, 可能な限り分節胃体部切除術を行なったが, 極めて高位で手技的に分節胃体部切除術の困難な症例飞 対しては噴門倒胃切除術を施行した。

また，併用する迷切術としてはSPVを目的としたが SPV 不能例にはSV を併用し幽門形成術を付加した。 SPV 旋行例です初期症例ならびに十二指腸潰湯共存例 には幽門形成術を付加したが，最近では幽門形成術を省 略しており，何ら不都合な症状の発現をみていない。

そこで，術後の胃分泌動能や ${ }^{99} \mathrm{~m} T \mathrm{c}$ による胃内容排 出試験からむSPV 併用術式では幽門形成術を付加する 必要がなく，良好な成績が得られることを報告した。

\section{來長総括}

長尾 房大

このセクションでは, 大潰湯, 高位漬瘍の病態, 治療 対策が論しられているが，外科適応としてのこのよらな 潰場の取报い方には，内科側からも必ずしも同意を得ら れていることであないので,このような分析を証拠とし て提示していくべきであろう．158では，大潰愓は出血 が手衍理由となることが多いのは周知のことであるが， 演者らによってその極めて高率 $(80 \%$ に近い)なこと が示され，深い，大きな潰湟底には露出血管の頻度す 高く，積極的な治療対策を講することの必要性を感ず る.大潰瘍の経過には縮少治瘾の攧向を示するのむある 
が，結局は再発再然によって治萝の望みは極めて少ない ことは内科側の珫計ですあることである．159〜161は， いずれも高立謴暍についてのすのであるが，高位謴晹に は，位固のみならず，発生因子，病態的にる問題になる 点が多く，またこれまです余り十分に分析されていな い情みがある１59では高位溲瘍には胃底腺区域の潰疸 が多いことを指摘し，かつ，濽晹周辺の粘膜が強く荒廃 しているので，噴切術が適当なことを強調している．噴 切に関しては，術後の胃機能を考虑して SPV との併用 を教室では年来推笑しているが，迷切各術式と噴切，分 節などの組み合わせに関する努力が160，161において報 告されたどのような術式がよいかは，高位潰偒の位直 のみでなく，病態を背景とした理論的な組み立てで決定 すべきであるが, 目下のところ，いろいろのアブローチ が試みられているのが現状である。いすれれる好成績であ ろのは同度の至りであるが，どれですよいのか，どれか に甘さが残っているのか，今後慎重に検討すべき問題と 思5。

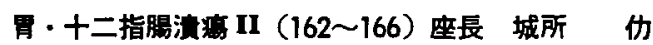

B-162. 選択的近位迷走神経切断術应例の検討 長崎大第 1 外科

石川 憘久, 松尾 和彦, 羅 向圭 小武 康徳, 石丸 宏哉, 千岩秀夫 北里 精司, 石井 绫世, 飛永 晃二 下山 孝俊, 内田 雄三, 三浦 敏夫 过 泰邦

過去 4 年間の十二指腸馈汪手術症例は89例で，その内 訳 は広範田胃切術 41例，選択的迷切術十幽門洞切除16 例，巽択的近位迷切術（以下 SPV と略す）31例であ る.SPVのらち最近の6 例には, SPV+幽門形成術に胃 前庭部横切術を施行している。

SPV の術後成績をみると酸分泌能の推移では術後 3 カ月が最す低く以後 2 年目頃まで上界がみられる。術後 3 年目の減酸率は $\mathrm{BAO} 60.7 \%$ ，MAO 58.4\%であっ た. 次に胃運動機能をみるため重複撮影をおこなった処， 胃前庭部の蠕動運動は活発で排出機能す良好であった。

アンヶート調查による術後の食事摄取状況では約半数 かi 3 力月末満に術前の食事量に回復し, 就労時期も1力 月以内に $50 \%$ が社会復㷌を果たしている．健康状態，衍 後愁訴の面からも他術式に比へ，極めて良好な成績を示 しており，SPV の約30\%に認められたアカラシフ様症 状与術後 4 力月以内には全例消失している. Ross and Kay 基準で late positive であった 1 例において 2 年半
後に胃溃場の発生がみられた。, 又, SPV の減酸率が他 術式に比へ低いため, 最近当教室では, SPV+幽門形成 術に幽門洞部之胃体部境界で前・後壁をそれぞれPetz を用いて横切離・吻合する方法を追加している。この術 式の目的は第 1 に胃幽門洞枝上行枝の壁細胞領域支配を 除くため, 第 2 にDebas らの云 5 "pylorooxyntic reflex, oxyntopyloric reflex”を遮断するためである.この術式 により術後 2 週間の減酸率は $86.6 \%$ と上昇し，術後重複 撮影による胃運動機能は強い正の蠕動運動が認められ， ハシリウムの排出も良好で, 術後愁訴の面でも極めて満足 した結果を得ている.

\section{B-163. SPV 施行店例の検討}

兵庫医大第 2 外科

$\begin{array}{lrll}\text { 橋本 } & \text { 直樹, 山村 } & \text { 武平, 琴浦 } & \text { 義尚 } \\ \text { 辰己 } & \text { 葵, 吉矢 } & \text { 健一, 楠 } & \text { 徳郎 } \\ \text { 三浦 㮌郎, 石川 } & \text { 羊男, 伊藤 } & \text { 信義 }\end{array}$

当教室開設以来 3 年半に手術を行った消化性潰痬症例 は208例で，このらちSPV を施行した十二指腸謴瘍症例 36例，分節胃切に SPV を併用した比較的高位の胃潰瘍 症例24例の計60例について検討した. 十二指腸溃瘍症例 での SPV は，前期 (S 50.6〜 S 51. 3) 後期 (S 51. $4 \sim S 52.9$ ）に分類し，後期では幽門枝の近位側第一 枝の迷切及び腹腔内食道周囲のいわゆる skeletonization を EC の上約 $5 \mathrm{~cm}$ 迄丹念に行った．前期および後期の 症例での平均減酸率は各々，BAO $(70 \%, 80 \%)$, ガス トリン (G) 刺敫下の MAO (45\%, 54\%), インシュ リン (I) 刺激下の PAO $(68 \%, 80 \%)$, 肉汁 (M) 刺 激下の MAO (50\%，65\%) となり後期の症例が良好な 減酸率を示す傾向が認められた.SPV と血中Gの関俰で は各刺激に対するGの反応性を示す Peak/basal (P/B) は，I，M両刺激とも後期に括いてゃや低下の傾向があ り，減酸率の面に扎いて後期の力が良好な結果と一政し ているょうに思われ，術式の改善に由来している可能性 が示唆された．比較的高位の胃溃瘍で分節胃切+SPV を施行した症例ではG刺激での MAO 減酸率約65\%， I 刺激での PAO 減酸率約 $80 \%$ となり, SPV のみの症 例に類似した隇酸率であった。この場合血中 Gの動態む SPV のみの症例でI 刺激を行った時の上䒜パターンと 類似する結果が得られた．術後愁訴では SPV 及び分節 胃切+SPV 症例とも再発の兆候を示す症例は全くなく， 術直後約 $20 \%$ にアカラシア様症状を呈したが早期に消失 した. 以上十二指腸潰湯に対する SPV 及び比較的高位 の胃溃瘍に対する 分節胃切+SPV は現在迄のところ良 
好な成嚗を得ているが，術後最長䄪 3 年の経過であり， 特に前期の SPV 症例で，BAO，MAO のかなり高い症 例があることから，今後とも慎重に経過観察する必要が あるむのと思われる．

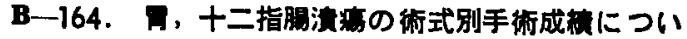 $\tau$}

藤沢市民病院外科（消化器）

O笠岡 千孝, 山岸 俊彦, 藤沢 祥夫
杉田 秀雄, 伊藤 進, 金子 等
小林 俊介

近年，本邦においてて十二指腸溃瘍に対する外科療法 として, 従来の広範胃切除術のみでなく, 強力な減酸効 果を得るため迷切を附加する術式が広く採用されるよう になってきた。一方, 胃溃湯に対しては潰痬部を含めた 胃切除が一般的であり，ほぼ術式は限定されている.今 回は胃潰湯，十二指腸潰湯について，術式別手術成績の 相異を比較検討し報告した。

過去 5 年間に外科治療を行った胃，十二指腸溃晹 211 例の5ち，術後 1 年以上を経過した症例，胃遗瘍93例， 十二指腸潰浧91例についてアンケート調查（回答率，胃 潰瘍 $83.9 \%$ ，十二指腸潰瘍 $83.5 \%$ ）を中心に術式別術後 成绩を 検討した。胃溃痬は胃半切除と広範胃切除の 2 群，十二指腸潰濍は迷切兼幽切，迷切兼 $1 / 2$ 幽切，迷 切兼幽成および広範胃切除の 4 群について比較検討を行 った．胃潰湟に招いては，切除範囲による術後成績の差 異はほとんど認められなかったが，十二指腸潰痬におい ては，ダンピング症状，下㢉，体重の項目で術式間にか なりの相異を認めた．即ち，ダンピング症状は迷切兼幽 切例及び広範胃切除例に中卢頻度が高く，下莉は広範胃 切除例及び全幹迷切例に高頻度に認められた．体重に関 しては胃の切除範囲が㹟い程良好な成綪を示した。

アンケートに対して「完全に満足」と回答し，術後 愁訴のない症例の中に，胃潰瘍発生をみた症例 (SV+ Jaboulay，術後 3 年; insulin test late positive, 減酸率 $70 \%) か ゙ 1$ 例あったので，十二指腸嘳瘍の迷切兼幽成群 については長期にわたる定期的検査が必要であると思わ れる。

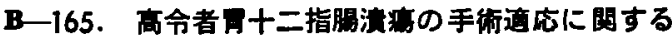
模剑

横須賀共斉病院外科

江口英雄, 辻仲 康伸, 国松 尚一

鬼頭 文彦, 鉿木 文彦, 中村 玄行 洲崎 兵一
過去 5 年間の消化性溃瘍手術症例数は胃溃煌90例，十

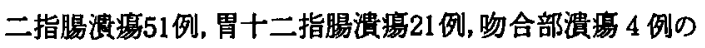
合計166例である.このうち高龄者は29例で全体の $17.5 \%$ にあたる．40歳以下の術後合併症発生率は $5 \%$ だるの に対し，60歳以上の高龄者では24.1\%と非常に高率であ る. 高路者の術後合併症は非合併症謴瘍では腾炎, 無気 肺各 1 例でいずれる軽症であった. 出血や穿孔を伴う合 併症蛽湯では心不全，腎不全，心不全と肺水腫など重篤 な合併症を併発しておりらち 2 例は死亡した．そこで高 路者手術症例を中心に検討した. 術前諸検查では堅, 肺 機能異常は10\%台に対し心機能異常は45\%であった．術 後合併症を起こした症例は術前著明な低蛋白と盆血がみ られた。胃潰煬発生部位では高位が半数以上を占めてい た、潰瘍の大きさでは $1 \mathrm{~cm}$ 以上が $80 \%$ である．特に出 血症例では $3 \mathrm{~cm}$ 以上が 6 例中 4 例を占めており巨大潰 啺は出血しやすいと思われる．潰瘍の深達度は，非合併 症潰湯でも70\%が Ul-IVであるが，出血症例では10例中 9 例が Ul-IVであり 5 例は穿通症例であった.

高龄者の消化性濽煌の緊急手術は術後合併症発生率, 死亡率が高く極力避けることが望ましい，従って臨床経 過，レントゲン写真，内視鏡所見などより巨大溃瘄で Ul-IVあるいは穿通を是われる場合には手術を行った方 がよいと思われる。

Bー166. 消化管ホルモンよりみた吻合部暴瘦の病䈍 順天堂大消化器外科

塩野溜，渡部 洋三，沢田 芳昭

宮上 寞之，近藤度一郎，城所仂

術後消化性潰瘍の発生原因の中で留意すべきるのはン゙ リンジャーエリンン症候群である。この場合，繰り返す 術後消化性潰瘍, 目瘍の触知, 胃液酸度の非常なえ進等 を示す例ではセクレチン負荷試験を始めとする血清ガス トリン測定を行ならべきである。すた前回までの手術法 がB-II法の場合には幽門脏置が原因のことが多く，こ の場合にはセクレチン負荷により血清ガストリンが抑制 されるのが特徽である.S.V.+P 後はG-cell hyperplasia を来しその為 Basal gastrin (B.G.) は上昇する.また 肉汁，インシ シン負荷試験共に Integrated Gastrin Response (I.G.R.) る上昇する.これは negative feedback 機構の破綻によると思われる.S.V.+P では以上 のことから迷切が不完全の場合，再発の危険性をるつと 思われる.このよ5に幽門粘膜の牫存はやがて街後消化 性潰湯の原因となり得るので幽門粘膜の残存態度により B.G. をみると幽門脏㯰例で $170.6 \pm 31.0 \mathrm{pg} / \mathrm{ml}$ と著明に 
高い，幽門粘膜が残っていても非脏置例では，非残存 例と同様に B.G. は低い。昡置粘膜の $\mathrm{G}$ 細胞の電顕でる その数は增加して找り，B.G. 上界の裹付けと考えられ る. 幽門粘膜の 残存態度により各種負荷試鈳の I.G.R. をまとめると、テストミール負荷では，幽門粘膜残存で 上昇，幽門昡置で中程度上昇，非残存例で隇少してい る. インシュリン負荷では幽門昿置で上昇，幽門粘膜残 存で中程度上算と減少, 非残存で咸少している。セクレ チン貞荷では幽門残存で上昇, 昿置, 非残存では反応し ない，Ca 負荷では 2 群に分かれる.このように幽門粘 䀧硗存を疑ったら肉汁とせクレチン負荷で，幽門脏置を 虔症例では肉计，インシュリン，セクレチン負荷試験 でその有無が判明する.なお S.V +P 後の消化性溃場で は血清ガストリンが高値を示すことを念頭において対処 すべきである。

坐長数括

城所 仂

B 162，163はSPV に関する演題である.SPV は Pyloroplasty，喷切， segmental resection なととと併用し て行なわれているか，何れる幽門部保存術式であるので 街後るガストリンの分必が行なわれ，壁細胞領域の条件 如何によっては充分な減酸効果の得られないことがあ る. また，充分壁細胞領域の denervation が行なわれてい ても術後年数の経過とともに減酸効果が減弱して来るの が一般的に認められている。.B162では幽門輪切除を并 用した 1 例を報告し排出機能佀問題があったと言う。B 163では衍後胃夜酸度をガストリン,インシュリン, 肉 井の三刺激を用いて测定し三者の堿酸率を比較してお ク，何れる城酸率が充分でないことから， denervation の徽底化沶よび Latar jet 幽門洞第一枝の切断を実施 して効果を高めることを提唱している。これに関連して achalasia 様症状を来たす例もあるが一時的で問題はな いと言う.この問題について田北教授より同様の趣旨の 発言があった。

B 164は 5 年間の 消化性潰萄手術症例についてアンヶ 一ト調査にもとつく術式別の術後成績を報告したもので ある.これに関しては特に質疑応答はなかった。

B 165は高龄者消化性潰瘍の術式および術後合併症を 㢵討した成績の報告である.高龄者の手術では心，肺， 祭の合的症が発生しやすいので手術時間の短縮, 患者の

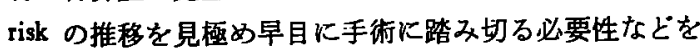
强調している.㗨急手術として十二指腸溃湯穿孔例に大 網充填術を施行して好成績を得ているとの報告があり， これに関する討論があった. 即ち simple gastrectomy
は短時間で終ることが出来，かつ侵㜔も少なく，再手術 を考悤する必要るないので胃切除でよいのではないかと する意見と，大網充填がりり安全で老人穿孔例には用5 べき方法であるとする意見のそれぞれの主張があった。

B 166は吻合部潰晹症例を 原因別に分析し，その原因 探究には各種負荷試験による血清がストリン，セクレチ ン負荷による血清ガストリン測定などが不可欠であると いら報告である．本演題については特に質疑応答はなか った.

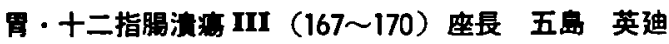

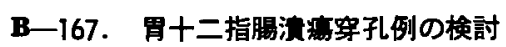

横浜市立大第 1 外科 藤本 泰則

昭和 45 年 3 月か 551 年 12 月までに教室の胃十二指腸潰 瘍手術総数383例中，胃穿孔 6 例，十二指晹穿孔69例の 75例の溃瘍穿孔例を経験した。年龄は30歳から50歳代に 多く，压倒的に男性飞多い。診断根拠となる遊離ガス像 は, 93.3\%に認められたが，3例の被輹性穿孔例には認 められなかった。白血球增多は10,000以上が60\%に認め られたが，約10\%は7,000以下であった。手術々式は広 䉪胃切を基本として71例に行ない，胃内容持続吸引と强 力な化学療法を行なった 3 例と大網被覆法 1 例は後に待 期的胃切除を行なった。紫急手術を行なった72例は全例 洗浄を行ない，66例に誘道を行なった．直接死亡は3例 で，急性肝不全 1 例，肝督症候群，睛不全各 1 例で，5 ち 2 例に肝硬变，腎機能障害が術前に併存していた. 穿 孔より手術までの時間よりは，むしろ穿孔口の大きさと 胃内容の有無に腹膜炎のつよさは関保し，衍前合併症が 予後を決定する重要な因子と思われる。

術後 1 年以上経過した67例に，術後状態に関してアン ケート調查を行ない，53例の回答を得たが，呕気，腹 満，胸やけなどの愁訴が58.5\%にあり，早期ダンピング か5 例淄められたが, 症状発現頻度は極く稀れにみら れる程度であった。体重回復は， $58.5 \%$ が術前にもど り，增加例は13.2\%であったが，食䬣攝取量は，術前と 同量, 增加した例が64\%あり，回復に要した期間は 6 カ 月以内か $49 \%$ \%て，2 年以上のものが $20 \%$ みられた.フン ケートで得た 1 日提取総カロリー量は，全例とも成人標 準摂取量に達していた。術後の仕事に対する意欲は，旺 盛, 普通と答えた例が88\%を占めていたが，39\%の症例 が仕事の種類, 内容の变更を行なっていた，早期ダンピ ング症状を除いて再建術式の差は認められない。

愁訴のあった 7 例飞, ${ }^{99} \mathrm{~m}$ Tc シンチグラムを残胃に行 なったが，残存幽門部は認められなかった。

B-168. 51年度高知県下における胃・十二指腸穿孔 
51例について

近森病院外科

山下 彦王, 近森 正博, 豊崎 七之 三井記念病院外科 古賀 和美

徳島大第 1 外科 青木 克哲

高知県下 162 の医療施設の協力をえて，昭和51年度中 に実施された胃・十二指腸穿孔51症例をまとめて報告す ろ.51例中 2 例は胃癌穿孔でしたが他は凡て溃痬穿孔で した. 手術症例は官公立病院に比へてて私立の病院の方に 3 倍近く泟例が集っており，月別には1月，4月，8 月，10月，12月に比較的多く発病しております，年龄的 には50歳を境にして，胃穿孔は，50歳以上に，十二指腸 穿孔は50歳以下に多く，一番若いのは15歳の 男性でし た. 病歴の明らかな42例で既往歴との関係を見ると，約 70\%が既に溃瘍の既往があり，又穿孔症例の半数は一定 期間入院又は通院加療を受けて括ります，術前の腹部レ 線検査では十二指腸穿孔の場合27例中26例と殆んど全例 に遊䧺ガス像を羿めだが胃穿孔の場合は約半数にしか認 めておりません。

胃，十二指腸穿孔は普通腹部敫痛を伴って哞病するの で殆んどの症例は穿孔より24時間以内に手術が施行され ていますが，中には 5 日以上と云らのが 4 例ありまし た。術式は各医療施設により異るが十二指腸穿孔はB II が多く，胃穿孔はB I と B II が殆んど同数でした。籍合 閉鎖の行なわれた 3 例は 3 例とも死亡しており，そのう ち 2 例は75歳の女性で胃癌穿孔，1例は74歳の男性でし た。これらは全身状態が要く胃切除術等の手術に耐えら れなかったものと考える．尚迷切は1例むありませんで した，最後に本調査にご協力いただいた各医療施設の方 々に厚くお礼申し上げます。

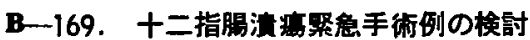

東京女子医大消化器病センター外科

$\begin{array}{lrcr}\text { 菊池 } & \text { 友允, 川田 } & \text { 彰得, 恩田 } & \text { 光憲 } \\ \text { 小川 } & \text { 健治, 大谷 } & \text { 洋一, 朝戸 } & \text { 末男 } \\ \text { 勝呂 } & \text { 衛, 横堀 } & \text { 直孝, 鈴木 } & \text { 茂 } \\ \text { 鈴木 }\end{array}$

十二指腸漬瘍の手術適応に関して，出血，穿孔，㹟窄 などの潰場合併症を引き起こした場合絶対適応があると されている，なかでも大出血および穿孔の場合，早期の 適確な診断とショック対策も含めた適切な外科的処直が 必要とされ，緊急手術の対象となる。

われわれは，1969年から1976年の8 年間に449例の十 二指腸謴湯に手術治療を行っているが，緊急手術例は出
血11例，穿孔36例の計47例で，そのちち出血 2 例穿孔 5 例を失っている.これら需急手術例において予後に影䈉 する因子につき臨床的検討を加えてみた，出血性十二指 腸溃湯については，明らかな吐・下血を主訴としてス院 しているものとし，毉急手術例は，入院48時間以内のも のとし即時手術もこれに含めた．出血例の場合緊急入院 したもののらち緊急手術となったものは，11例（11.8 \%)と少なく，穿孔の場合の緊急とは报いが違うすので あると言える.緊急手術後の死亡例について険討してみ ると高龄者および術前に合併症を有するむの，又穿孔例 に朔いては，手術までの経過時間などが予後を左右する 大きな因子であると思われる。

B-170. 高張ブドウ糖溶液の十二指渴内注入による 胃酸・ペプシン分泌抑制について一胃十二指腸暴瘦症例 を中心に一

東京大第 1 外科

平田忠, 谷 昌尚, 高橋 忠雄
朝郎 貞雄, 井原悠紀夫, 武部 硐郎
小西 富夫, 山岸 健男, 島津 久明

目的：胃液分泌の腸相における変化を知るために，胃 十二指腸潰瘍を中心とする臨床例の十二指腸内に高張ブ ドウ糖溶液を注入し，その胃酸・ペプシン分泌反応に及 ぽす影饗について検討を加えた。

方法：胃十二指腸潰瘍をはじめとする臨床例の胃と十 二指腸内にX線透視下で各 1 本のチューブを挿入し，胃 液採取用のチェーブは胃底部に，十二指腸チューブはそ の先端が可能な限りトライッ靯帯の近くに位固するよう に操作した。貯留胃夜を排除したのち，30分間の基礎分 泌を採取し，ついで AOC-tetrapeptide $4 \mu \mathrm{g} / \mathrm{kg} / \mathrm{h}$ の投与 を持続点滴静注法で 2 時間行ない，分泌された胃液を10 分分画で連統採取した。テトラガストリン刺激開始60分 後，胃酸分泌反応が一定となった時点で浸透仕 2,865 $\mathrm{mOsmol} / 1$ の50\%ブドウ糖溶液 $40 \mathrm{ml} 5$ 分間かけて十二 指腸内に注入した。採取した胃液は，胃酸を PH スタ ットを用いて湘定し，ベプシンを Anson の変法に従っ て測定した。

成績及び結論：1）テトラガストリン投与のみを行な った場合の胃酸分泌反応は，刺激開始後次第に胃酸分泌 量が増加し，40分でピークK達し，2時間後迄そのレべ

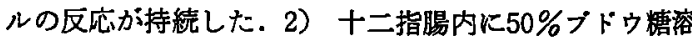
液 $40 \mathrm{ml}$ を注入すると，その直後より約 30 分間持続する あきらかな胃酸分泌の抑制が認められ，3）その抑制は 胃液分泌量の減少に起因し，胃液酸度には変化が認めら 
れなかった，4）ペプシン分泌も同様の抑制反応が認め られたが胃酸の場合と異なり，その濃度む低下する為 に，さらに著明な抑制傾向が認められた５）十二指晹 漬瘍症例でこの抑制機構が特に傽害されている事実を示 暖する成紸は得られなかった。

座長稔括

五岛 英迪

胃十二指腸惯瘍穿孔症例についての検討 3 題と，胃酸 分泌に関する演題が 1 題である.

先の 3 題についてロ演を拝聴し，まとめて討論をする こととした。

B-167席の栱浜市大藤本氏は，释験した呀孔例75例に フンケート調查を行い，その予後について良好な成績を 披歴している。術後の再発に分泌細胞残存の可能性を論 し， ${ }^{9 \mathrm{~m}} \mathrm{Tc}$ のシンチグラムが有用であることを述べてい る.

B-168席の近森病院山下氏は，高知県下 160 施設で昭 和51年度中に経験した穿孔症例55例をまとめて報告して いる. 十二指腸穿孔と胃穿孔では年㱓的要素が異るこ と，多くの患者はすでに医治を受けている症例であるこ とをあげている。

B-169席, 東大 1 外菊地氏は，出血症例をも含め緊急 手術症例について述べ，449例中36例が穿孔で, $8.0 \%$ を占 め, 死亡 5 例と比較的多いことについて言及している。

以上 3 演題について，演者相互の討諭はなく，座長か ら問題点を $2 ， 3$ あ゙てみた。

Free Gas が認められない場合，特別な診断の手がか りはないだろらか。

藤本氏は，方向，体位等， $\mathrm{x}$ 線写真の撮り方により， 正面像のみからは見られない所見を得ることがあり，又， 胃管㨉入後送気により Gas の増強を期待することもあ る旨述へる。

山下氏は，症例の多くが，他病院の症例で，方法の詳 紐はわからないが，腹部所見によって診断は容易であ ると述べた。

菊地氏に代り榊原氏が立ち，すへてを若い医師の診断 に任せているわけではないので，かなりな経験の上で， 多角的な診断をしていることを述べた。

更に，本症は救急手術を必要とするので，術前充分な 検査が不可能なことが多い，手術死亡例を検討した結果 から示唆することはないであろらか。

藤本氏の報告では，75例中 3 例死亡，中 2 例は肝硬変 症が原因であったと云ら。菊地氏の報告では，36例中 5 例死亡, 死亡例について特別な険討はないが，50歳以上
の症例で, $28.6 \%$ に術後合併症があり, 年龄的因子の予 啳に対する影響の大きいことを述べている.

女子医大柛原氏から，藤本氏に Drain を 2 カ所に入れ る理由を質問されたが，明確な返答は得られなかった。 Drain は充分に洗涤し得た症例では全く用いないことも あり，危険を残すと予湘した場合は 4 カ所以上に入れる こともあるので答弁しにくかったものと思う。

最後に B-170. 東大 1 外平田氏の口演では，胃酸ぺ ブシン分泌反応を，十二指腸内に高張ブドウ糖溶液を入 れることによって観察し，多くの症例で，抑制し得たと 報告した.

この口演に対し, 兵庫医大から, 高張糖以外のものて やった経験，又その抑制機序について質問があった．然 し時間が不足して充分な討論が出来なかった．座長の不 明の為は恥じている。

胃手術I（171～174）座長 浜中 良郎

B-171．近位胃切後消化宫の再建術式の工夫，とく に近位空晹分節有䔔移植について

大阪市大第 2 外科

東野 正幸, 酒井 敏之, 裴 光男

大杉 治司，吉岡 幸男，染谷隆

小合 孝之, 荒矢 覚, 山戸 庸光

平田 早苗, 橋本 寿雄, 浜中 良郎

白羽弥右衛門

過去 7 年間にわれわれの外科で行なわれた胃全剔およ び近位胃切は合計184例である。その消化管再建術式に は，前半 3 年間，条件の許すかきり主に食道十二指腸間 空腸分節有茎移植を行なったところ，術後の逆流性食道 炎発生は少なく，脂肪吸収率の高いことが確認された。 それで，最近では胃全剔空腸分節有茎移植の適応を限定 するようになった。一方これまでに行なわれた胃全剔 および近位胃切群の術後血清鉄と血清中 V-B - $_{12}$ の推移 をみたところ, 近位胃切例ではかなり有利な結果が得ら れた。また, 癌腫がCに限局していた症例で， $\mathrm{S}_{0}$ およ び $\mathrm{S}_{1}$ の症例には $5 ， 6$ 番のリンパ節転移陽性例はみら れなかった。そこで，癌腫がCに限局し，その墏膜浸潤 か $S_{1}$ までの症例に対しては近位胃切除を行ない，その 口側に約 $20 \mathrm{~cm}$ 長の空腸分節を有茥移植するよらになっ た. 本術式を施された11例の術後 $\mathrm{X}$ 線検査により3型を 分類することができる．I 型：試験食が残胃内にほとん ど貯留せず，残胃が単なる道管になっているもの（残胃 が術前胃の1/3以下の 3 例), II 型：残胃内に食物がよく 貯留されるが，十二指腸内への排出が遅れるもの（残胃 
が1/2の 2 例)， II 型：残胃内詝留がよく，十二指腸内へ の移行がスムーズなるの（残胃が1/2以上の 6 例)。それ ゆ六，残胃の大ささは術前胃の1/2以上が望ましく，ま た残胃の大きさに対応する幽門形成を検討する必要があ る、なお，牫胃の大きさに合わせて空腸分節を調節し， 全長 $40 \mathrm{~cm}$ 以上に保てば，逆流性食道炎を防止すること ができるようである。

Bー172．胃ドレナージとしての幽門输状切開術に関 する検討

\section{国立舞鶴病院外科}

宮下 史郎，鳥井 剛司，春日 正已 今城 茂良，鹿野実

滋賀医科大第 1 外科 恵谷 敏, 大同礼次郎

脱神経胃のドレナージとして，Heineke-Miculicz 法 が多く行われているが，食道再建に利用した胃管にこれ を行えば短縮が来るため，我々は短緶を防き，更に胃管 の延長を計るため, 幽門輪より口側約 $0.5 \mathrm{~cm}$ 部, 更に $0.5 \sim 1.0 \mathrm{~cm}$ 離れて $2 \sim 3$ 条の幅 $1 \mathrm{~cm}$ の全筋層粘膜外 輪状切開を加之，右胃，胃大網動脈より胃に流入する血 管を避りて行い，筋切開創からの出血は充分に止血を行 5, 胃管延長は, 約 $6.5 \mathrm{~cm}$ (平均値) が得られ,これに より頝部吻合部まで充分の長さの胃管が得られだ.

今回は 3 年以前よりこの方法で食道再建に使用した胃 管の特に幽門部の通過状熊をレ線透視，三栄測器の低 圧 electromanometer と斉藤氏イレウス管のバルンを使 用して壁内压曲線をとり，検討を加えたが，HeinekeMiculicz 法に比して何等愿色がなく通過状態は極めて 良好であった。

B-173. 大桐引入れ充填術による B I 法早切除後 合不全に対する!治駼例

日本医科大第 2 外科

○望月 功, 野中 達也, 土屋 喜哉 金内 秀士，松林富士男，庄司佑

我々は，胃十二指腸穿孔に対し，大網引入れ充填術を 施行し，良好なる結果を得ている事を，発表して来た が，今回，BI法胃切除後絴合不全に対し，胃内容物の 腹腔内への流出及び，穿孔部位の修復機転など，胃十二 指腸穿孔と，同じ考え方に基つく治療法が成り立つるの と考光，施行し，良い結果を得た。

大網を穿孔ロより引き入れる事により，腹膸内への胃 内容物の流出を防き，大網よりの新生血管か，粘膜下層 に入り込み，粘膜再生が容易となる。よって胃酸の影響
を受けにくくなるわけである．完全に粘膜が再生した時 期汸於て，筋層に於ける穿孔口は，大網血管之脂肪組織 で置換されているが，既に胃酸の影響はこの部位には及 ばなく、ゆっくり線維化がはじまり，肉芽が抗こるので ある。

以上の棣な理論根拠の基に，今回の桻合不全症例に対 し大網引入れ充填術を施行した.

患者は, 胃演瘍のため，B I 法胃切除を施行, 行後10 日目に絴合不全を併発しガストログラフィンによるX 線検査に於て，吻合部より，造影䨩の大量漏出を認め た. 49歳男性である.

再開腹し，大網引入れ充填術により，術後 1 週間目火 は, 腹膜炎症状が消失し，20日目には，軽快退院した。

以上 1 例ではあるが，胃十二指腸穿孔と同じ考方方に より大網充填術を施行した，B I 法胃切除後稌合不全应 例を報告する。

B-174. Billroth I法に於けるI屈吻合，II届吻合 の比較梌討

日本医科大第 2 外科

$\begin{array}{rrrr}\text { 大場 } & \text { 英巳, 石村 美樹, 原 } & \text { 一郎 } \\ \text { 吉田 } & \text { 洋, 中村 隆, 望月 } & \text { 洋 } \\ \text { 高橋 } & \text { 正人, 松林富土男, 庄司 } & \text { 佑 }\end{array}$

佼成病院外科 佐藤 蕉隆

Billroth I 法胃切除に於ける吻合法として，従来から 獎膜面を重視する II 層吻合と最近では，粘膜下を重視す るI 層吻合がある。

我々の教室及び関連病院で，昭和50年より現在まで， I 層吻合 100例，II 凮吻合 110 例を行なった。我々の行 なっている I 層吻合は, Jourdan の吻合法に似ているる のである. 残胃及び十二指側の吻合予定線に沿って全 周に，䉃膜，筋層と割を入れ粘膜層のみを残す．胃・十 二指腸吻合の運針操作は, 漿膜, 筋層, 粘膜下織と針を 通し, 対側はその逆の順に行なう.この様なI 凮吻合 と, 従来からの II 層吻合の術後早期合併庠としての, 吻合部の出血, 㹟窄, 桻合不全について両者を比較して みる. 比較には, 軽度, 中等度, 強度の 3 段階とした。 出血は I 層例では, 軽度 2 例，II 㬝例では 8 例で, むし ろ I 層吻合で心配された出血は少なかった，狭窄はI 層 に軽度17例，中等度 1 例，II 㬝に軽度 17 例，中等度 2 例

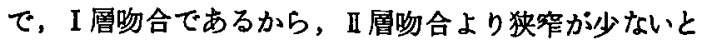
云ら事はなかった。繾合不全は，対症療法中手術を要し た中等度以上のものを見ると，I層では1例，II㬝で は2例であったＩI 層の释合不全例の 1 例は，73歳男， 
幽門狭窄，煻尿病を合併，又皮后疾患の為10年間ステロ イドを使用中であり，血清総蛋白は $3.2 \mathrm{~g} / \mathrm{dl}$ の条件下で 手街された例である．I 層吻合の繸合不全に関してる， II層吻合と比較して劣るほどの成績ではなかったＩ層 吻合に関して、これだけの症例で云々することは早計に 失するの諒りを免がれ奴がこれまでの経験ではより 安全の様に感しられた。

\section{座長地括浜中 良郎}

B 171 席は近位胃切食道残胃間空腸分節有茎移植に関 する演題であったが，本法の手術適応として，噴門部の 良性疾患および噴門部に限局した癌，とくに早期のるの と䈋膜浸潤 $\mathrm{S}_{1}$ 症例まで含めていると発表された。これ に対して， $S_{1}$ 例では幽門下リンパ節に転移が認められる 症例のあることが報告されており，危険を伴らのではな いかとの質問があった，演者は，実際に癌に対して本法 が行われたのはわずか了例であり，他はすべて良性疾患 に対して行われた。しかむ， $S_{1}$ 例は肉眼的にはあるかな いかの䓧めて小さなものであり，術中の肉眼所見では， 幽門下リンバ節の腫大は認められなかったとの返答であ った.

B 172席の胃ドレナーシとししての幽門輪状切開術に関 する検討に対しては，一般からの質問がなく，來長か， 術後どの位の期間を㧊いて検討しているかを質問した。 これに対して演者からは，術後 3 年位のすのもあるとの 返答であった. 実際に本法に，これまでの幽門形成と同 棣の働きがみられるならば，理想的な方法であると思わ れた。

B 173席発表の䋖合不全に対寸る治療法としては大絧 引入れ充填術が有効であった症例について報告された。 これに対して狭窄を伴ら十二指腸溃瘍穿孔例でる本法の 適応となりえるかとの質問がなされた。演者は，本法が 行われた十二指腸溃瘍穿孔症例のながは狭窄例は認め られていない。どうむ，十二指腸溃瘍には，穿孔をきた す型と狭窄をきたす2型があるよらな感じがするが，勿 論狭窄例には本術式は適当でないと考兄ているとの返答 であった。

B 174席の発表は, 胃切除後 Billroth I 型胃十二指腸 吻合法として 1 層物合と 2 層吻合の湢床成績を比較検討 したあのであり， 1 層吻合は 2 層吻合に比べて優ると も劣らない成績であったと報告された。1 層法は Gambee が小腸拈よび大腸の吻合に採用して以来，わが国に おいてす普及しつつあり，その治瘾過程からみても，合 理的な繾合法であると考えられるので，今後さらに広く
用いられるよ5に思われた。

胃手術 II (175 178) 座長 赤井 貞彦

B-175．胃全剔後再建法選択に䦕する一考察（特に 胸腔内碳入法に就いて

関東遁信病院消化器外科

$$
\begin{aligned}
& \text { 谷村 修, 武井 秀夫 } \\
& \text { 園田 俈志, 斉藤 光 }
\end{aligned}
$$

近年, 胃恶性腫湟に対する積極的な手術姿勢及び払大 根治術の導入に上り根治性を満足すへくく胃全剔症例は増 加しつつあるが，他方それに伴う致死的合併症に発展し らる縫合不全の予防は手術の成否を左右するといっても 過言ではない，縫合不全の最大要因の一つは吻合部の過 㗨張であると思われるが，今回我々は該部の緊張解除を 目的とした1972年10月以降実施した胸腔内岸入法に就き 検討した。

当科の過去 8 年間の胃全剔総数は64例（内悪性腫組59 例）であったが，我々の非開胸的全剔は根治性を考文切 除線は E-C Junction より oral $2 \mathrm{~cm}$ で再建術式は全迷 切後の食道の伸びと収縮を考虑に入れた Roux en $\mathrm{Y}$ 法 施行. 吻合は二層繾合にて行い，次いで吻合部を後維隔 内に嵌入. 吻合部脱落防止の為, 腹膜と空腸を数針固定

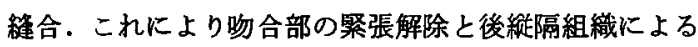

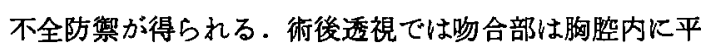
均 $3.6 \mathrm{~cm}$ 嵌入し，又，食道にアコーディオン様収縮状 態は無い，即ち、この距離に相当する緊張䌅和が得られ た事になる，以上の嵌入を行った後期を嵌入をしない前 期之縫合不全率を比べると前期 $5 / 23(21.7 \%)$, 死亡率 $100 \%$ ；後期 $2 / 41$ (4.9\%) で後期は何九も minor leakage で保存的に治㽷，死亡率0\%であった．又，後期の 不全例は 2 例共, 従来の不全例と臨床症状，経過を異に し，レ線では術後 1 週目で限局性鄎室様の造影剤漏出を 認め,ドレナージを行ら事なく絶食と胃ゾンデ減圧のみ にて経過観察． 2 调目では辺縁一部突出像のみにて経口 摄取開始. 4 週には不全の痕跡むなく狭窄むなかった。 術後経過名通常手術経過と变らず，頻脈，白血球增多す なく従来の不全例とは全く異った経過であった，以上胃 全剔後絴合不全予防策としての嵌入法の有用性を報告し た。

\section{B-176. 胃全摘再建術式の検討}

県立がんセンター新潟病院外科

花岡 農夫, 佐々木寿英，島田 寬治 五十川久士, 加藤 清, 前田 政克 佐野 宗明, 赤井 貞彦 
当外科に於て1967年以降10年間の胃癌手術症例は 1818 例，胃切除1357例中胃全摘は296例（全摘宰21.8\%）て あり手術死亡は 4 例（直死率1.3\%) である，その遠隔 成結は治腹切除 $38.9 \%$ 非治珻切除 $14.5 \%$ である.胃全摘 後の再建術式について，(1) 再建法と早期合併症，(2) 再建法之逆流性食道炎，(3)各再建術式の消化吸収，(4) 根治度と再建術式について検討を加えた。1974年 4 月 までは188例中175例（93\%）が B-田法による再建であ り，その後1976年12月までは B-II法11例， R-Y 30例， Double tract 24例, Inter position 42例之再建術式に大 きな変要がみられる。(1) 早期合併症については䋖合不 全 B-II 法 3 例 (1.6\%)，R-Y 2 例 (5.5\%) I-P 3 例 (6.9\%) DT 1 例 $(4.1 \%)$ で直接死に結びついたもの 1 例. 後出血は 5 例あり 4 例再手術し 1 例直接死亡であ る. (2) 胸やけが週 3 回以上のものを重症例とするとBII 法69\%，R-Y 29\%，IP 11\%，DT 0\%，食道内 $\mathrm{pH}$ 。 B-I法は高值を示し腸液の逆流が示唆された。内視鏡所 見では，B-II 法90\%に高度の食道炎所見を認め，Roux-Y は色調変化型が $60 \%$ IP，DT では20数\%にそれを 認めた（3) 消化吸収試験では榶質，蛋白質に関しては 明らかな差異はなく脂質代謝では特に B-II法の代謝障 害が同われた. (4) 以上の諸方面よりの检討の上当科に 於ては B-II法は全く現在行っていない, Roux-Y は非治 绮切除例又は poor risk のものに行っている. 根治性の 高いむのは主に IP，DT，を用いていすすが DT は総合 的にも優れた再建術式であり今後む症例を積んでゆきた い。

\section{B-177．胃悪性嘎满に対する胃全摘症例の検討} 川崎市立川崎病院外科

$\begin{array}{rrrr}\text { O前原 } & \text { 正明, 斉藤 } & \text { 敏明, 山田 } \text { 良成 } \\ \text { 東條 } & \text { 慧, 新井 } & \text { 健之, 堸米 } \\ \text { 寛 } \\ \text { 横山 } \\ \text { 水渡 } \\ \text { 哲史 }\end{array}$

1970. 1 1977. 5 まで約 7 年間に，当院で施行された 胃悪性盾湯に対する胃切除は，246例で，内，胃全摘56 例 (23\%) について検討を加えた．胃癌53例，胃肉尰 3 例であった. stage 別では, stage I 4 例，II 5 例，III 14例，IV33例で， stage III，IVが84\%を占めていた，再 建術式別では，Roux-Y 41例 (73\%), Interposition 13例 (23\%)，B-II 2 例 (4\%) であった. 又，治瘾切除31例 (55\%), 非治瘾切除25例 (45\%), 直死例 2 例 (4\%) であった. stage III，IVが84\%と多いにもかかわらず， 治㾌切除が55\%あるのは，合併切除が30例 (54\%) d存
在するためであろ5，術後合併症では，肝障害 $18 \%$, 肺 合併症 $14 \%$ ，イレウス $5 \%$ ，艇合不全 $4 \%$ ，創感染 $4 \%$ に みられた. 1974.1 1 で前期，後期を分けてみると，䀒障 害は，前期 $35 \%$ ，後期3\%，イレウスは，前期 $12 \%$ ，後 期 $0 \%$ と共に前期症例に多かった。これは，前期の方 が，手術時間む長く，出血量む多かったためと思われ る. 挥合不全は 2 例で, Roux-Y 1 例 Interposition 1 例で，いずれも食道空腸端々吻合例であった。術後39， 26日目に経口開始となり，軽快している．全症例56例の 追跡調查の結果, 不明者 3 , 生存者 21 , 死亡者 32 , 再発 入院中 4 であった。生存者17例に対し，アンケート，個 人面談により，現在の状態を術式別に検討すると，現在 の体調良好者，Roux-Y 56\%，Interposition 71\%，術前 と同じ仕事をしているもの，Roux-Y 33\%，Interposition 100\%であった，遠隔成績では，3年生存率， stage II $38 \%$, stage IV 19\%，治痹切除39\%，非治㾰切除 $17 \%$, 5 年生存率, stage III 25\%, stage IV 17\%であった. 全症例の 3 年生存率は，30\%，5年生存率は，25\%であ った，以上の結果より，症例数が少ないが，释合不全に 関しては，食道空腸端側吻合，退院後の状態について は, Interposition の方がよいように思われる. stage III IVの症例の中には，合併切除により，積極的に治殓切除 をめざせば，かなり予後が期待できる症例るあると考兄 られた。

Bー178. 高カロリー輸湾を中心とした胃全剔術後の 䋖合不全予防対策

\begin{tabular}{|c|c|c|}
\hline 科大 & -般消化器外 & \\
\hline ○坂東 & 平一, 小坂 & 進, 古川 \\
\hline 土原 & 一弘, 木藤 & 光彦, 山下 正洋 \\
\hline 野口 & 昌邦, 滝田 & 佳夫，有賀藤一郎 \\
\hline 松入 & 伸夫, 高田 & 道明, 北谷 \\
\hline
\end{tabular}

胃癌に対する胃全剔はその根治性は勿論，安全性と術 後合併症および術後愁訴の少いことが要求される，私共 はこの観点からその再建術式は Interposition を第 1 選 択とし，術後は程合不全予防と栄美管理の面から第 1 又 は第 2 病日より10〜14日間 IVH を施行し，経口栄盖は 第 8〜第10病日より開始した。な括管カテーテルは㨉 入しない.

1974年 9 月より1977年 5 月までの胃全剔症例27例のう ち25例に術後 IVH による管理を行なった．縫合不全は 治病切除 $0 / 19$, 非治疼切除 $2 / 6$ と治痹切除群には極めて 有効である。

膵脾合併切除例に対しては脺炎，脺瘦の予防，膵液の 
るれの減少奻果がある様に思われ，更に栄養状態の回復 が早く癌化学療法をスムースに行なえる等のメリットが ある.

㹐後の経過を血清アルブミンの推移からみると術前 $3.5 \mathrm{~g} / \mathrm{dl}$ 以上の症例では $30 \sim 39 \mathrm{cal} / \mathrm{kg} / \mathrm{day}$ の維持カロリ 一で血清フルブミンの術直後の低下す小さく，その回復 る良好で，赭合不全は充分に予防し得る。濃度も高くな いので管理あ比較的容易である. 術後血清アルブミンが $2.5 \mathrm{~g} / \mathrm{dl}$ 以下になると栈合不全を生ずる可能性が大き く, 術前 $3.4 \mathrm{~g} / \mathrm{dl}$ 以下の例, 非治疼手術例，その他全身 的, 局所的因子の加わる例では $40 \mathrm{cal} / \mathrm{kg} /$ day 以上の維持 カロリーが必要である. surgical diabatasに関しては25 例中5例に insulin 投与を必要としたが control は容易 であった，血清電解質の control も特に困難ではない。

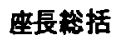
赤井 貞鹿

このセクションはすべて胃癌胃全剔術をテーマとした 㴼題であるが，B-178及び178は释合不全対策をとりあ げ，B-176及び177は胃全剔術全般特に再建術式に重点を おいた発表であった。

最近ではいずれの施設においても胃全剔術の直死率は 低下して来たが，その大きな原因は吻合，中でる食道・腸 伆合の释合不全発生の減少である. B-175の演者はRouxen-Y 法の食道空腸端々昒合の手技について述へ，特に 物合部を後綎隔内に嵌入し，さらに周囲を数針固定する 点を強調した。これに対し松林教授は吻合部が腹腔内に あることが特に不利ではないこと及び固定はむしろよく ない操作ではないかと発言された。演者の成績が後半特 に向上した理由はいくつかあろうが，むしろ注意深い吻 合手技こそが無視できない原因ではなかららか？B-178 では胃全剔全例に高カロリ一輸液を行い空腸有茎移植の
敕合不全を予防しらることが述べられた。確かに本法を 施行すれば術後長期に亘り栄荃管理を行らことが可能と なる.従ってたとえ minor leak が発生してもこれを早 々に治病せしめることはありらるであろう．

この様な試みは臨床研究として重要であり，今後の発 展が期待されるところである。しかし，本法はいかに熟 鍊したチームによって行われても，な相且つ従来の末梢 輸液法よりは不断の細かな配虑が要求される．従って一 般臨床外科の立場からすれば胃全剔のすべてに不可久の 方法とは言いがたいと思われる。

B-176では各種吻合法が比較検討され，B-II 法が逆流 性食道炎の発生率が高く，消化吸収の面でもバラッキが 大きく，Roux-en-Y 法, Double tract 法, 空腸有茥移植 の3者，特に後 2 者がすぐれているとされた、これらは いずれむ食道，空腸端々吻合であったが光野教授から輸 入脚を長くした $\rho$ 型の端側吻合が消化吸収試験ですぐれ た成績を示すことが述べられた，B-177では殆ど全例が Roux-en-Y から空腸有茥移植が行われ，しかもその多 くが端側吻合であるが，その近隔，遠隔成績共に優秀で あり，B-178と共に释合不全は3\%台に止まっていた。

田中早苗教授は「胃手術の寸べて」の中「胃全剔術」 の冒頭に「胃全摘そのむのの技術はざど困難な仕事で はない，‥再建には殊に消化，吸収の点などにす多くの 問題を蔵し…と述べておられる。それから約 9 年を経 過した現在，以上の 4 題からも伺える如く，吻合法には Roux-en-Y, Double tract, 空腸有茥移植が多く行われる 様になり，食道炎発生は減少した。しかし，今後は田中 教授の指摘された如く，胃欠除による消化，吸収障害を 如何にして補正するかが大きな問題となるものと思われ る。

\section{B 会場 午後の部}

上部消化管出血 $(179$ ～183）座長 赤木 正信

B-179. 上部消化管出血に対する薬物的迷走神経切 到（medical vagotomy）の効果と限界について

横浜市立大第 2 外科

O杉山 貢, 山中
磄边, 滝沢 利男
土屋 周二

過去 9 年間に当外科で経験した上部消化管大量出血例

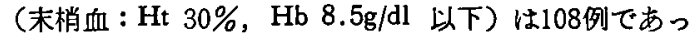
た。手術前に診断の確定したすの，または非手術前に診 断の確定したもの，または非手術例で診断し得たものは 77 例 $(71.3 \%)$ であり，疑診例で診断の的中例：16例 (14.8\%)，診断不能は15例 $(13.9 \%)$ であた。急性 出血性胃びらんとストレス潰場の診断では18例中 6 例に しか確診できなかった．今回，これらの症例の内，大量 出血早期に保存的治療として薬物迷切を 30 例に施行し 